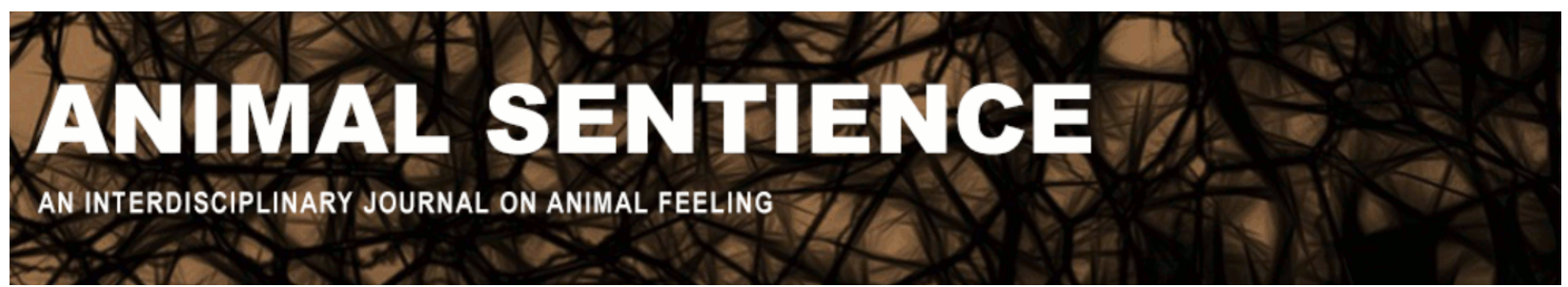

Marino, Lori (2016) Why animal welfarism continues to fail. Animal Sentience $7(5)$

DOI: $10.51291 / 2377-7478.1084$

Date of submission: 2016-02-02

Date of acceptance: 2016-02-05

(c) (†)

This article has appeared in the journal Animal

Sentience, a peer-reviewed journal on animal

cognition and feeling. It has been made open access,

free for all, by WellBeing International and deposited

in the WBI Studies Repository. For more information,

please contact

wbisr-info@wellbeingintl.org.

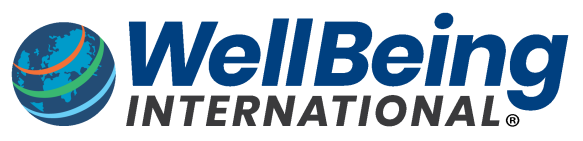

SOLUTIONS FOR PEOPLE, ANIMALS AND ENVIRONMENT 


\title{
Why animal welfarism continues to fail
}

Commentary on $\mathrm{Ng}$ on Animal Suffering

\author{
Lori Marino \\ Kimmela Center for Animal Advocacy, Utah
}

\begin{abstract}
Welfarism prioritizes human interests over the needs of nonhuman animals. Despite decades of welfare efforts other animals are mostly worse off than ever before, being subjected to increasingly invasive and harmful treatments, especially in the factory farming and biomedical research areas. A legal rights-based approach is essential in order for other animals to be protected from the varying ethical whims of our species.
\end{abstract}

\begin{abstract}
Lori Marino marinolori@outlook.com, neuroscientist, former faculty affiliate at the Emory Center for Ethics and Executive Director of the Kimmela Center for Animal Advocacy, has authored over 100 publications on dolphin and whale brain evolution and anatomy, intelligence and self-awareness, and the effects of captivity on social mammals, including cetaceans, elephants and primates. She worked with the Nonhuman Rights Project and is featured in the film Blackfish. http://www.kimmela.org
\end{abstract}

In his target article, $\mathrm{Ng}$ (2016) takes a classic welfarist approach to animal protection, invoking the "difficult problem" of the World Knot (Schopenhauer, 1906/2014) as justification for maintaining the status quo. Welfarism is a stance that prioritizes human interests over those of other animals (Donaldson \& Klymicka, 2011), and is perfectly exemplified in Ng's statement:

"There are simple ways to reduce animal suffering substantially at a very low or zero cost - or even a net gain - to humans." (p. 4)

But this kind of actuarial approach to animal protection will always subjugate the needs of other animals to human desires, providing incremental changes within existing systems of abuse and exploitation.

Welfarism is tantamount to "ethical gerrymandering" (Marino, 2011). When there is a conflict between human and nonhuman interests, the human interests almost invariably dictate the meandering border of ethics, which allows for animal protections as long as they do not inconvenience humans. For example, the Animal Welfare Act (1994) addresses the treatment of "laboratory" and "warm-blooded animals" with the exception of rodents, birds and "farm animals," thereby gerrymandering its regulations (and thus creating a legally fictitious category) 
to suit the needs of a large segment of the human population who would find the goal of protecting these categories of nonhuman beings too unwieldy or threatening.

Even after decades of animal welfare efforts all over the world and endless discussions and debates in the literature, nonhuman animals are mostly worse off than ever before. (The few exceptions to this trend would include the decrease in the number of homeless dogs and cats, being killed in shelters in the U.S.) From 1950 to 2014, the number of animals slaughtered in factory farms in the United States alone ballooned from 100 million to more than nine billion (USDA, National Agricultural Statistics Service). Despite "humane" labels and modifications in cage sizes, more factory farmed animals are being subject to increasingly invasive genetic, physiological and behavioral procedures than ever before (Ormandy, Dale, \& Griffin, 2011). Examples include transgenic pigs and sheep who have been genetically altered to express higher levels of growth hormone and move from birth to "the table" as quickly as possible (Laible, 2009), and featherless chickens (Wells et al., 2012).

Another area in which welfarism has been, arguably, unsuccessful is in the use of other animals as biomedical models. An animal model is an animal sufficiently like humans in anatomy, physiology, or psychology to be used in research considered too harmful or risky for humans. The animal model meets a kind of taxonomic equivalency to humans so as to react to manipulation in a way that resembles the human response. We decide through historical consensus that members of other species can be like us in ways that are convenient and yet dissimilar in ways that would be inconvenient if acknowledged otherwise. Therefore, by its very nature, the use of animal models is ethical gerrymandering, creating contorted justifications for the use of other animals as a means toward an end.

Despite welfare regulations at academic, government and private laboratories, and the lipservice paid to "alternatives" to animal experimentation and "regulatory oversight," increasingly invasive manipulations have proliferated in basic and applied research around the world (Dow \& Lowe, 2012; Nestler \& Hyman, 2010; Ormandy, Dale, \& Griffin, 2011). Examples include humannonhuman animal chimeras (Behringer, 2007), like mice with human brain cells (Windrem et al., 2014) and pigs used to grow human organs for xenotransplantation (Reardon, 2015; see NIH videocast of "Workshop on Animals Containing Human Cells"), and the creation of autism in transgenic monkeys (Liu et al., 2016). While one might argue that without welfare considerations animals would be subjected to even more harmful manipulations, these recent research developments make it clear that welfarism has "set the bar" absurdly low.

In addition to these major causes of animal suffering, we must add the growing number of industries aimed at cloning and genetically manipulating pets (Fiester, 2005) and extinct wild animals (Cottrell, Jensen, \& Peck, 2014). Ng seems unconcerned about mass extinctions, with little insight into the urgency of the situation or, perhaps more importantly, the very real connection between our disregard for wild animals in their habitats and the suffering and death of all animals in laboratories and factory farms. 


\section{Why a legal rights-based approach is essential}

The weaknesses of welfarism are brought into stark contrast when one considers that, despite numerous organizations and efforts claiming they work for "animal rights," no nonhuman being anywhere has any rights. They are all considered legally to be "things," pieces of property that lack the capacity to have even the most rudimentary rights. A number of philosophers have proposed a rights-based approach to animal protection (Regan, 2005; White, 2007) but these are not legal rights; rather, they are viewed as moral rights or natural (inalienable) rights that must rely on the human community to recognize and respect them and are, therefore, vulnerable to the same kinds of ethical gerrymandering we see in welfarism. Just as has been the case for subgroups of humans throughout history, the strength of legal rights for other animals is that they are defensible and enforceable despite differences in public opinion about their merits.

Critics of a rights-based approach tend to focus on the false-assumption that nonhuman animal rights are equivalent to human rights. Obviously, no serious proponent of animal rights accepts that premise. Rights should be species-specific. However, at the most fundamental level, all animals (human and nonhuman) share two very basic natural rights, which seem to be inarguable from any reasonable standpoint and yet are reserved for humans exclusively. The first is bodily liberty, i.e., freedom from being held in confinement or captivity against one's will, and the second is bodily integrity, i.e., freedom from being touched or manipulated physically without one's consent or one's best interests (Wise, 2003). These two basic rights alone, if recognized legally, would prohibit essentially all of the kinds of treatments currently deemed permissible under welfarism.

The fact that even these two rudimentary rights have been difficult to obtain for even great apes, who are the most obvious nonhuman legal plaintiffs, exposes our inability to tolerate even the smallest degree of equality with other animals. However, just as welfare was not enough for human slaves, women and children in the past, true "protection" for other animals will only come with the capacity for specific legal rights.

\section{References}

Animal Welfare Act. (1994). 7 u.s.c. §2131-2159.

Behringer, R. R. (2007). Human-animal chimeras in biomedical research. Cell Stem Cell, 1(3), 259-262.

Cottrell, S., Jensen, J. L., \& Peck, S. L. (2014) Resuscitation and resurrection: The ethics of cloning cheetahs, mammoths, and Neanderthals. Life Sciences, Society, and Policy, 10(3), doi: 10.1186/2195-7819-10-3.

Donaldson, S., \& Kymlicka, W. (2011). Zoopolis: A political theory of animal rights. Oxford University Press.

Dow, L. E., \& Lowe, S. W. (2012). Life in the fast lane: Mammalian disease models in the genomics era. Cell, 148(6), 1099-1109. 
Fiester, A. (2005). Ethical issues in animal cloning. Perspectives in Biology and Medicine, 48(3), 328-343.

Laible, G. (2009). Enhancing livestock through genetic engineering - Recent advances and future prospects. Comparative Immunology, Microbiology and Infectious Diseases, 32(2), 123-127.

Liu, Z. (2016). Autism-like behaviours and germline transmission in transgenic monkeys overexpressing MeCP2. Nature, doi: 10.1038/nature16533.

Marino, L. (2011). Ethical gerrymandering in science. Journal of Animal Ethics, 1(2), 199-121.

National Institutes of Health. (2015). Workshop on Animals Containing Human Cells, http://videocast.nih.gov/summary.asp?Live=17471\&bhcp=1.

Nestler, E. J., \& Hyman, S. E. (2010). Animal models of neuropsychiatric disorders. Nature Neuroscience, 13, 1161-1169.

$\mathrm{Ng}$, Y-K. (2016). How welfare biology and commonsense may help to reduce animal suffering. Animal Sentience 2016.007.

Ormandy, E. H., Dale, J., \& Griffin, G. (2011). Genetic engineering of animals: Ethical issues, including welfare concerns. The Canadian Veterinary Journal, 52(5), 544-550.

Reardon, S. (2015). New life for pig-to-human transplants. Nature, 527(7577), 152-154.

Regan, T. (2005). Sentience and rights. In J. Turner \& J. D'Silva (Eds.), Animals, Ethics and Trade: The Challenge of Animal Sentience. London: Earthscan.

Schopenhauer, A. (2014). The World as Will and Idea. London: Dobimick Publishing.

Wells, K. L., Hadad, Y., Ben-Avraham, D., Hillel, J., Cahaner, A., \& Headon, D. J. (2012). Genomewide SNP scan of pooled DNA reveals nonsense mutation in FGF20 in the scaleless line of featherless chickens. BMC Genomics, 13.

White, T. (2007). In Defense of Dolphins: The New Moral Frontier. Malden, MA: Wiley-Blackwell Publishing.

Windrem, M. S., Schanz, S. J., Morrow, C., Munir, J., Chandler-Militello, D., Wang, S., \& Goldman, S. A. (2014). A competitive advantage by neonatally engrafted human glial progenitors yields mice whose brains are chimeric for human glia. The Journal of Neuroscience, 34(48), 1615316161.

Wise, S. M. (2003). Drawing the Line: Science and the Case for Animal Rights. Cambridge, MA: Basic Books. 


\section{“I Am Not an Animal!" \\ The Signature Cry of Our Species

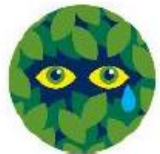

ur fellow animals and the Earth are under increasing threat from human activities. Anthropogenic climate change, habitat destruction and an unfolding mass extinction all beg the key question: Why are we incapable of changing our behavior?

At this unique two-day symposium, we look at how our behavior is driven psychologically by the need to see ourselves as separate from and superior to the rest of nature. And we ask why we need to keep telling ourselves, through our actions and belief systems, that "I am not an animal!"

We explore this exceptionalist view of ourselves with leaders in the fields of psychology, ecology, ethics, philosophy, law and advocacy. And we discuss how we can apply their insights to environmental and animal protection efforts.

WHEN February 24-25, 2017

\section{WHERE} Emory Conference Center

1615 Glifton Road NE, Atlanta, GA 30329

Organized by Lori Marino, John Schacke, Michael Mountain

REGISTRATION \& FULL INFORMATION www.not-an-animal.org

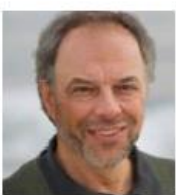

The State of Planet Earth Today

Keynote address: Author and conservationist Carl Safina takes stock of what scientists are calling the Sixth Mass Extinction and where it may be heading.

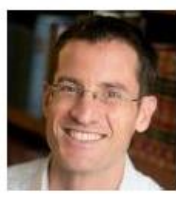

Our Planet \& Ourselves in

History and Mythology

Bioethicist Jonathan Crane talks

about the stories we've told

ourselves over the millennia about our origins and our relationship to the other animals.

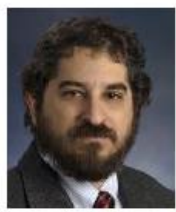

How We "View" Other

Animals

Randy Malamud, Prof. of English, Georgia State University, author of Reading Zoos, discusses the psychology of keeping animals in zoos, aquariums and circuses.

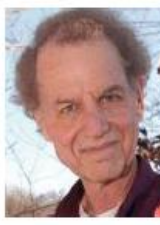

Some We Love, Some We Hate, Some We Eat

Hal Herzog, author, Emeritus Prof. of Psychology, Western Carolina University, explores the confusing relationships we have with different kinds of animals.

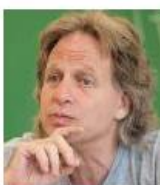

The Worm at the Core Sheldon Solomon, author and Prof. of Psychology, Skidmore College, explains how our civilization and culture act as a defense against the anxiety we fee about our mortal, animal nature.

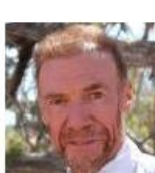

"I Am Not an Animal!"

Michael Mountain, former President of Best Friends Animal Society, discusses how advocacy efforts are hobbled by people's denial (often-subconscious) that we humans are animals, too.

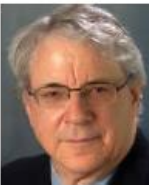

Nonhuman Animals as Legal Persons

Steven Wise, President of the Nonhuman Rights Project, explains how the legal system treats nonhuman animals as "things", as it once did with slaves, women and children.

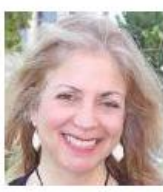

Someone, Not Something Lori Marino, Director of The Kimmela Center for Animal Advocacy, talks about how we are coming to see other animals as "someone" rather than "something" - as individuals in their own right.

Group Discussion

What do these insights indicate for environmental and animal protection efforts?

\section{SCHEDULE \& DETAILS}

www.not-an-animal.org 